\title{
Remote sensing as a tool for bathymetric mapping of coral reefs in the Red Sea (Hurghada - Egypt)
}

Bathymetrisch karteren van de koraalriffen in de Rode Zee (Hurghada, Egypte) met behulp van teledetectie

Tony Vanderstraete, Rudi Goossens and T.K. Ghabour

\section{(2) OpenEdition}

Electronic version

URL: http://journals.openedition.org/belgeo/16652

DOI: $10.4000 /$ belgeo. 16652

ISSN: 2294-9135

Publisher:

National Committee of Geography of Belgium, Société Royale Belge de Géographie

Printed version

Date of publication: 30 September 2003

Number of pages: $257-268$

ISSN: 1377-2368

\section{Electronic reference}

Tony Vanderstraete, Rudi Goossens and T.K. Ghabour, "Remote sensing as a tool for bathymetric mapping of coral reefs in the Red Sea (Hurghada - Egypt)", Belgeo [Online], 3 | 2003, Online since 30 October 2003, connection on 05 February 2021. URL: http://journals.openedition.org/belgeo/16652 ; DOI: https://doi.org/10.4000/belgeo.16652

This text was automatically generated on 5 February 2021.

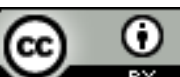

Belgeo est mis à disposition selon les termes de la licence Creative Commons Attribution 4.0 International. 


\section{Remote sensing as a tool for bathymetric mapping of coral reefs in the Red Sea (Hurghada - Egypt)}

Bathymetrisch karteren van de koraalriffen in de Rode Zee (Hurghada, Egypte) met behulp van teledetectie

Tony Vanderstraete, Rudi Goossens and T.K. Ghabour

1 For studying coral reefs, a bathymetric map is important as a base map. As it indicates the depths at which the corals occur, it can give an insight into the ecology of the reef system. A depth map is also useful in marine park management or risk assessment in case of, for example, oil pollution. Unfortunately, current bathymetric information on coral reefs is often non-existing, inaccurate or out of date (Mumby et al., 1998). Due to their rather shallow depth and/or often remote location in the middle of the ocean, it is not always suitable to conduct a conventional bathymetric echosounding campaign. Remote sensing techniques are often more cost-effective in gathering information over vast and remote areas without a restriction of shallowness. It also offers the opportunity to follow up the changing situation over time, making it possible to update existing nautical maps in short time notice.

Different methods have already been developed to map bathymetry using remote sensing. Two main groups can be distinguished. One group is using active remote sensing data; the other is based on passive sensor, multi-spectral information. In this article the focus is on the passive data method. The bottom-reflection based remote sensing theory (Ji et al., 1992), states that, up to a certain depth, part of the signal recorded by the sensor is reflected by the bottom. In clear, case I, water (Jerlov, 1976) the seabed can reflect enough light to be detected by a satellite sensor up to a depth of 30m (Green et al., 2000). Green et al. (2000) evaluated different passive data techniques (Benny \& Dawson, 1983; Jupp, 1988; Lyzenga, 1978; Van Hengel \& Spitzer, 1991). Based on the correlation between the depth calculated with the different methods and the actual depth of a control area, they concluded that the «Depth of Penetration» (DOP)- 
mapping method developed by Jupp (1988) was the most accurate. Therefore a DOPmapping method, modified by Green et al. (2000), was used in our study.

The basic principle behind the method of Jupp (1988) is that different wavelengths of light penetrate water to varying degrees. Longer wavelength light, red in the visible part of the spectrum, has a higher attenuation coefficient than short wavelengths, e.g. blue. There will be a depth, the maximum depth of penetration for red light, at which all the light detected by band 3 of the Landsat7 ETM+-sensor $(0.63-0.69 \mu \mathrm{m})$ has been fully attenuated. However, at this depth, there will still be some light that is detectable by bands 2 (green) and 1 (blue) of the ETM+-sensor. DOP-zones are delineated by the maximum depths of penetration of successive bands with shorter wavelengths (Green et al., 2000). Three additional assumptions were made to build up the DOP-method (Green et al., 2000): light attenuation is an exponential function of depth, and water quality and substrate do not vary within the image.

\section{Study area}

4 As study area, the coral reefs near Hurghada, Egypt, $\left(27^{\circ} 14^{\prime} \mathrm{N}, 33^{\circ} 54^{\prime} \mathrm{E}\right)$ situated in the northern part of the Red Sea, were selected (Figure 1). The coral reefs are located in a unique environmental setting: the enclosed Red Sea is completely surrounded by deserts, has almost no water input from rivers and hence very stable physical characteristics such as salinity, temperature and water quality. Although the coral reefs are not under great natural threat, they are suffering from the negative effects of booming tourism and from urban coastal development projects mainly for tourist accommodation and in support of the Egyptian relocation policy. 
Figure 1. Localisation of the main coral reef systems offshore Hurghada, Egypt, on a Landsat7 ETM+ True Colour Composite (Red, Green, Blue).

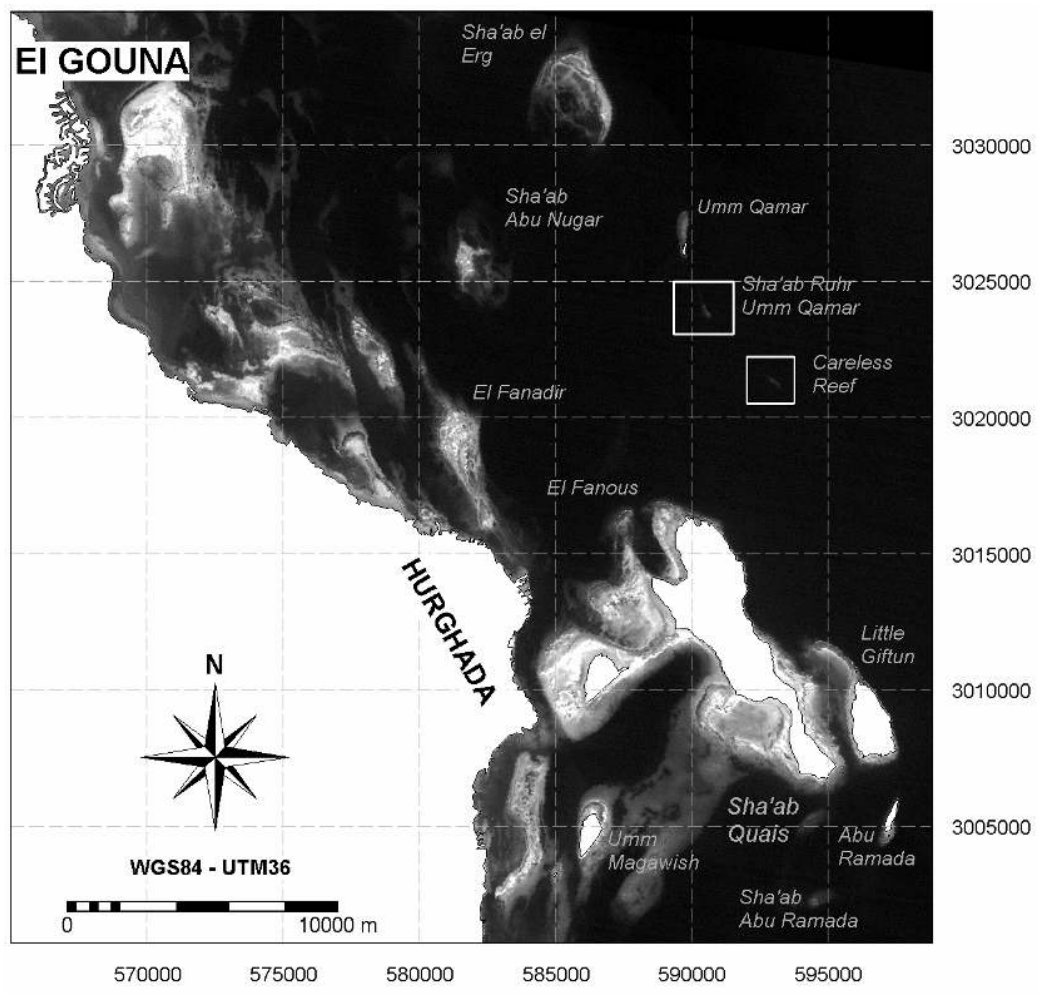

\section{Data Sources}

\section{Field Data}

Two field surveys have been completed between August 25th and August 31st 2001, and between March 28th and April 4th 2002. During these campaigns, 420 observations were made at sea. X- and Y-coordinates were measured using a GPS (Garmin GPS 12 XL) in the UTM36-WGS84 coordinate system. The positional error on the GPS-readings was in the order of 3 to $4 \mathrm{~m}$. Depth values were derived using a hand-held sonar (Manta Dive Ray DR-100) with an accuracy of $0.3 \mathrm{~m}$ above and $1.0 \mathrm{~m}$ below $10 \mathrm{~m}$. A Zodiac was used so as to reach shallow areas.

\section{Tidal Data}

6 The daily tidal range averages $0.6 \mathrm{~m}$ in the northern part of the Red Sea. This is augmented by a seasonal evaporation effect of an estimated $0.5 \mathrm{~m}$ between summer and winter (Edwards, 1987). It is important to compensate for the tide at image acquisition and during data sampling in order to produce a bathymetric map at datum. Tidal data were derived using the free tidal prediction program WXTide32 version $2.6^{1}$ for 3 stations in the neighbourhood of Hurghada, namely Shadwan Island $\left(27^{\circ} 17^{\prime} \mathrm{N}, 34^{\circ} 02^{\prime} \mathrm{E}\right)$, Quseir $\left(26^{\circ} 06^{\prime} \mathrm{N}, 34^{\circ} 17^{\prime} \mathrm{E}\right)$ and Ashrafi Island $\left(27^{\circ} 47^{\prime} \mathrm{N}, 33^{\circ} 43^{\prime} \mathrm{E}\right)$. The tide for Hurghada has been extrapolated using these data based on a weighted inverse distance method. The depths measured during field survey were then corrected to datum, i.e. lowest astronomical tide, based on these tidal values. The tide at the moment of the image 
recording (10/09/2000, 08:03 GMT) was calculated to be $0.24 \mathrm{~m}$ above datum (Vanderstraete et al., 2002).

\section{Satellite Data}

7 A level-2 Landsat7 ETM+-image (path/row: 174/041) dating from September 10th 2000, was used to determine the depth of the sublittoral zone in the study area. Wavebands 1 , 2 and 3 were used because these wavelengths are not totally absorbed by the water column. Waveband 4 was also involved for bathymetric mapping of the intertidal zone. The ILWIS 2.3-software ${ }^{2}$ was utilised to georeference a sub-scene covering the study area. As ground control points, 21 points, out of a total of 63 points measured on the land during the two field surveys, were used so that the resulting georeference-error (RMS $=0.406$ ) lay within the acceptable limit of 0.5 pixel. The georeference was based on a specific UTM-coordinate system (UTM R36-WGS84) using a «full second order» equation. Satellite images were only roughly atmospherically and radiometrically corrected.

\section{Modified «Depth Of Penetration» Mapping Method}

8 For a detailed description of the procedure of the modified «depth of penetration» mapping method the reader is referred to the «BILKO for WINDOWS-manual» (Edwards, 1999) and Green et al. (2000). The procedure can be split in two sections. First, the four different DOP-zones were determined and, secondly, the depth of every pixel in each zone was calculated.

\section{Determination of «Depth of Penetration»-zones}

9 The image has been divided into four different DOP-zones. Green et al. (2000) defined a DOP-zone as «a region in which light is reflected in one band but not in the next». For example, the first DOP-zone represents those depths in the image where only band 1 of the ETM+-sensor is still receiving some reflectance of the bottom. DOP-zone 2 has reflection in the blue and green band but not in the red and near infrared, and so on.

10 First, the reflection over a deep water area, $\mathrm{Li}_{\infty}$, needed to be determined. These deep water DN-values were determined in a subset of the image over an area with depths greater than $50 \mathrm{~m}$, as determined on a nautical chart ${ }^{3}$. It was assumed that over deep water the signal received at the sensor is entirely composed of reflection by the atmosphere, the water surface and the water column (Green et al., 2000). Therefore, the mean deep water reflectance, $\mathrm{Li}_{\infty}$ mean, was used to roughly correct for atmospheric and water column effects on the signal (Table 1). Furthermore, the maximum deep water reflectance, $\mathrm{Li}_{\infty} \max$, in each band was used to delineate the different exclusive DOP-zones (Table 3). If the DN-value in a waveband $\mathrm{i}$ is greater than $\mathrm{Li}_{\infty}$ max, some reflectance of the seabed is supposed to be present in the signal received by the sensor (Green et al., 2000).

11 Secondly, the maximum depth of penetration for the Landsat7 ETM+-bands 1 to 4 was calculated (Table 2). For each band i, this depth was determined by the deepest pixels with a DN-value greater than the maximum deep water value, $\mathrm{Li}_{\infty} \max$ (Edwards, 1999). 
Table 1. Maximum, Mean and Minimum DN-Value in ETM+ Band 1, 2, 3 and 4 over a deep-water area.

Band 1 Band 2 Band 3 Band 4

\begin{tabular}{|c|c|c|c|}
\hline Maximum DN-value for deep water ( $\left.L_{\infty} \max \right)$ & 65 & 41 & 36 \\
\hline Minimum DN-value for deep water ( $\left.\mathrm{L}_{\text {ios }} \mathrm{min}\right)$ & 56 & 34 & 26 \\
\hline Mean DN-value for deep water ( $\mathrm{L}_{\text {iø }}$ mean) & 60 & 37 & 31 \\
\hline
\end{tabular}

Table 2. Determination of Maximum Depth of Penetration for Landsat7 ETM + bands 1, 2, 3 and 4.

LANDSAT 7 ETM+

(Path/row: 174/41; date: 10/09/2000)

\section{Band 1 Band 2 Band 3 Band 4}

\section{Max. Depth of Penetration: $z_{i}(m) \quad 21.4 \quad 16.8 \quad 5.2 \quad 3.0$}

Table 3. Decision tree used to delineate the 4 exclusive DOP-zones.

\begin{tabular}{|c|c|c|c|c|c|}
\hline Landsat7 ETM+ band & 1 & 2 & 3 & 4 & DOP-zone \\
\hline$L_{i \infty} \max \quad 65$ & 41 & 36 & 21 & & \\
\hline If DN value of pixel & $>65$ & $\leq 41$ & $\leq 36$ & $\leq 21$ & Then depth $=] 16.8,21.4]($ DOP 1$)$ \\
\hline If DN value of pixel & $>65$ & $>41$ & $\leq 36$ & $\leq 21$ & Then depth $=] 5.2,16.8](\mathrm{DOP} 2)$ \\
\hline If $\mathrm{DN}$ value of pixel & $>65$ & $>41$ & $>36$ & $\leq 21$ & Then depth $=] 3.0,5.2](\mathrm{DOP} 3)$ \\
\hline If $\mathrm{DN}$ value of pixel & $>65$ & $>41$ & $>36$ & $>21$ & Then depth $=[0,3.0](D O P 4)$ \\
\hline
\end{tabular}

12242 observation points, out of the total of 420 , were used to estimate the maximum depth of penetration for each waveband. These points, taken over a fairly homogeneous sandy substrate, were selected based on their reliability. Observed depth values corrected to datum were referred to the tide at the moment of image acquisition. These points were then located on the georeferenced satellite image and the DN-value, for each band, of every observation point was determined (Figure 2). 
Figure 2. Relationship between dn-values and depth.

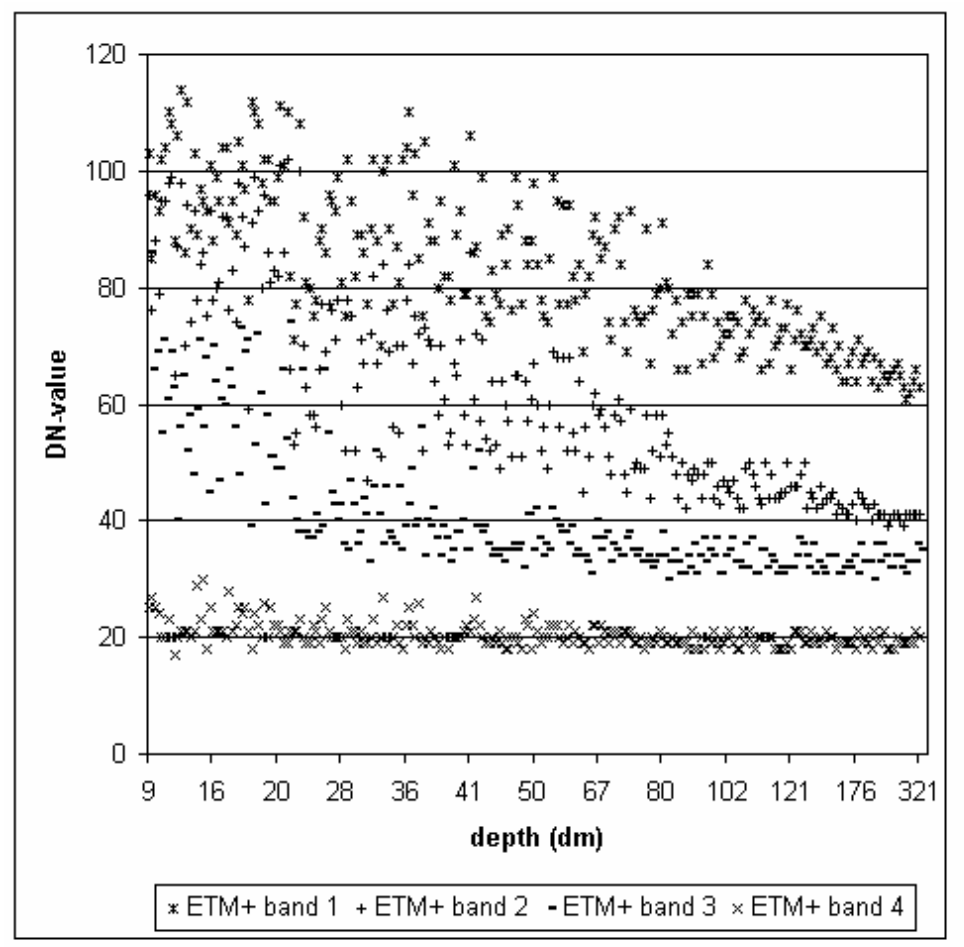

\section{Interpolation and Calibration of Depths within the DOP-zones}

In between the maximum depth of penetration for each band and the surface, assuming the substrate remains constant, the DN-value is purely a function of depth. According to the two-flow radiative transfer model, the radiance measured at sensor, $\mathrm{Li}$, of any submerged pixel can then be expressed as (Green et al., 2000): 
Jupp (1988) and Green et al. (2000) made following approximations for the unknown parameters $\mathrm{L}_{\mathrm{i}}$ surface and $\mathrm{k}_{\mathrm{i}}$ in the case of subsequent exclusive DOP-zones:

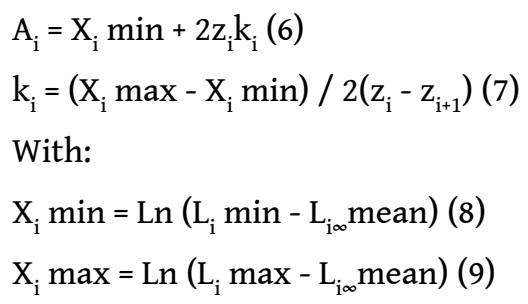

Where $L_{i}$ min and $L_{i}$ max are respectively the minimum and maximum DN-value in each DOP-zone; $z_{i}$ the maximum depth of penetration for DOP-zone $i$ and $z_{i+1}$ the maximum depth of penetration of the overlaying DOP-zone. The necessary parameters are summarized in table 4.

Table 4. Overview of required parameters for depth estimation.

\section{Band $1 \quad$ Band $2 \quad$ Band $3 \quad$ Band 4}

$\begin{array}{lcccc}\mathrm{L}_{\mathrm{i}} \text { deep mean (DN) } & 60 & 37 & 31 & 19 \\ \mathrm{~L}_{\mathrm{i}} \text { max. (DN) } & 68 & 63 & 82 & 99 \\ \mathrm{~L}_{\mathrm{i}} \min .(\mathrm{DN}) & 66 & 42 & 37 & 22 \\ \mathrm{Z}_{\mathrm{i}}(\mathrm{m}) & 21.4 & 16.8 & 5.2 & 3.0 \\ \mathrm{X}_{\mathrm{i}} \max . & 2.079 & 3.258 & 3.932 & 4.382 \\ \mathrm{X}_{\mathrm{i}} \text { min. } & 1.792 & 1.609 & 1.792 & 1.099 \\ \mathrm{~K}_{\mathrm{i}} & 0.031 & 0.071 & 0.486 & 0.547 \\ \mathrm{~A}_{\mathrm{i}} & 3.130 & 3.997 & 6.850 & 4382\end{array}$

\section{Results and discussion}

Equation 3 was then applied to band 1 for DOP-zone 1, to band 2 for DOP-zone 2; etc. The separate results for each DOP-zone were combined into one bathymetric map of the coral reefs near Hurghada, as can be seen in figure 3. Depths represented here are referred to datum. To check the accuracy of the resulting map, 100 independent field observation points were selected. The strength of correlation (Figure 4), expressed by the Pearson product moment correlation coefficient, between predicted depth and actual depth, and the average difference between measured depth and calculated depth were used as measures for the accuracy of the result. Residuals were determined by subtracting calculated values from measured values for each independent observation point (Table 5). 
Figure 3. Bathymetric map of the coral reefs offshore Hurghada.

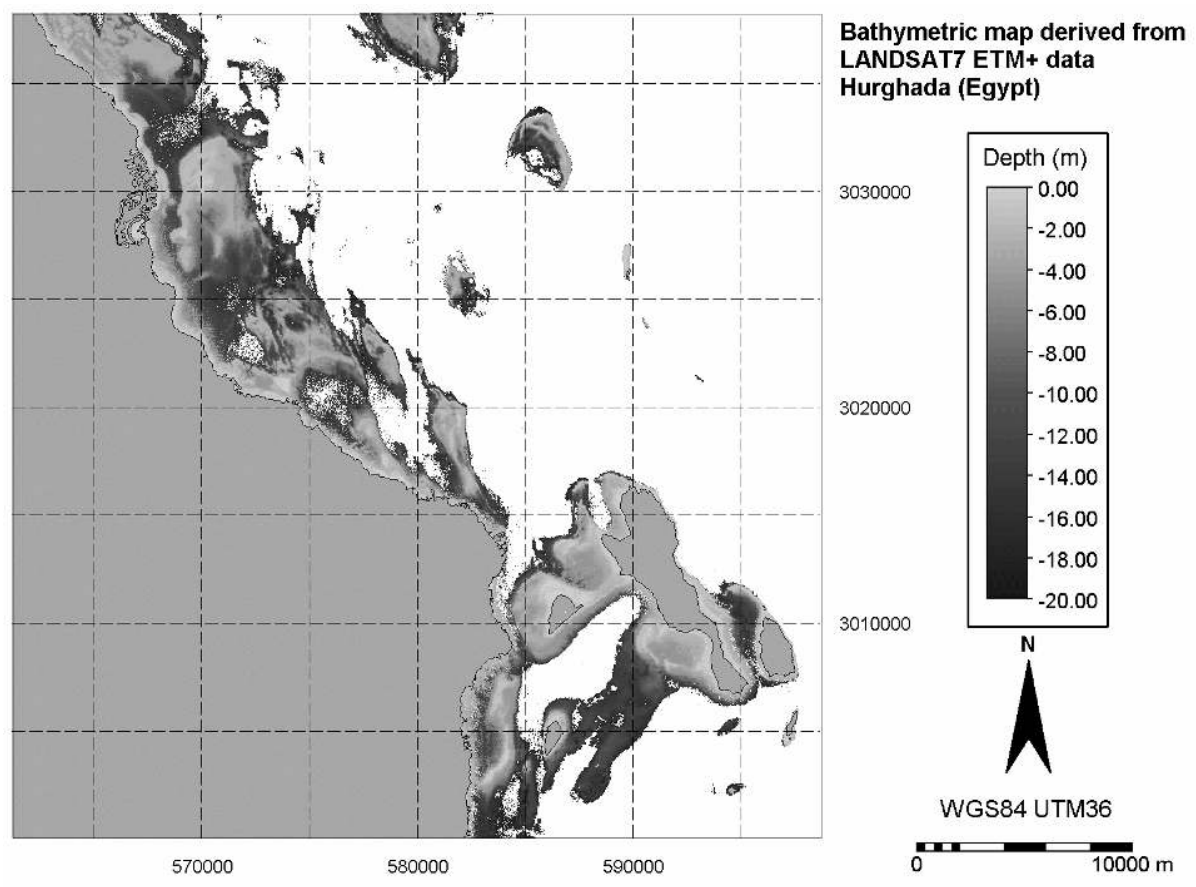

The Pearson coefficient (0.91) indicated a high correlation between real depth and depth estimated using the modified DOP-mapping method. This is in accordance with the results received by Green et al. (2000). Although the mean error $(-1.2 \mathrm{~m})$ was relatively low, the standard deviation $(2.1 \mathrm{~m})$ and RMS-error $(2.4 \mathrm{~m})$ were indicating some uncertainty about the resulting depth values (Table 5). A general overestimation of depth was noticed, especially for shallow areas (Figure 4). This divergence originated from different sources (Vanderstraete et al., 2002). 
Figure 4. Correlation between depth estimated by the modified dop-mapping method and true depth.

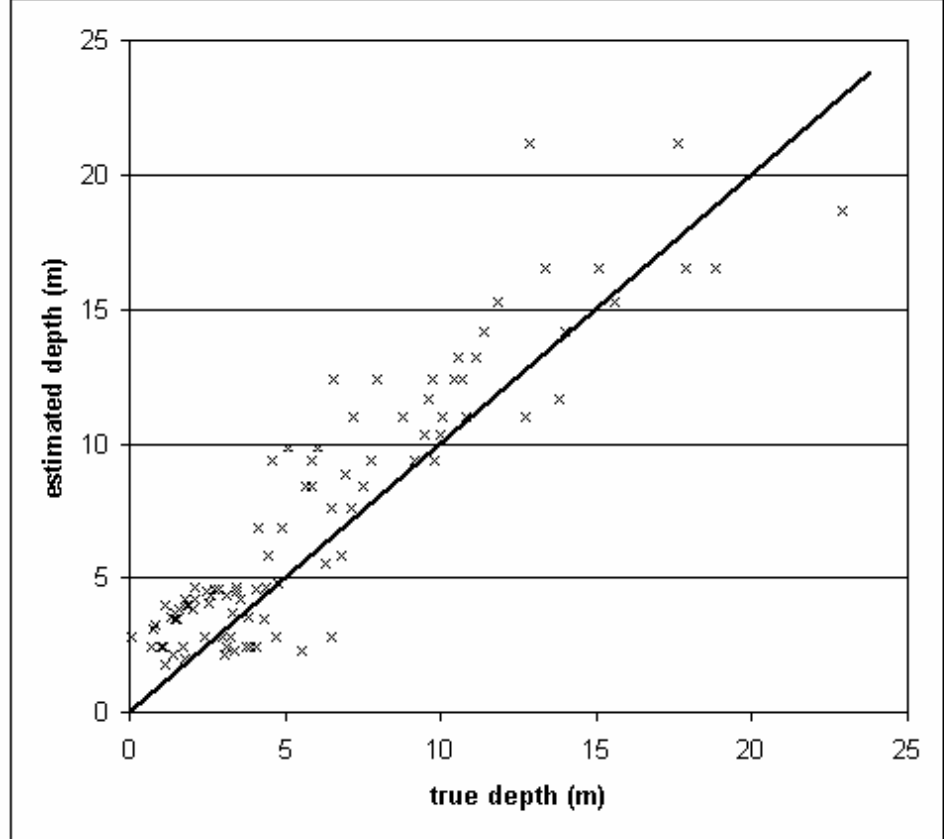

Table 5. Overview of parameters calculated for accuracy testing.

\section{Accuracy testing}

$\begin{array}{lc}\text { Pearson coefficient } & 0.91 \\ \text { Mean difference }(\mathrm{m}) & -1.2 \\ \text { Standard deviation }(\mathrm{m}) & 2.1 \\ \text { RMS-error }(\mathrm{m}) & 2.4\end{array}$

Some errors were caused by assumptions or formulas inherent to the method used. As already mentioned by Ji et al. (1992), the crude method of atmospheric and water column correction introduced an error in model calculations. Due to overreduction at optically shallow locations having lower water column contribution than expected ( $\mathrm{Li} \leq$ $\mathrm{Li}_{\infty}$ mean), a zero or negative value for ( $\mathrm{Li}-\mathrm{Li}_{\infty}$ mean) occurred. These values could not be used to calculate valid natural logarithms necessary in equation 5. Results should therefore be more accurate if radiometric and atmospheric corrections were applied to the satellite data. Unfortunately, ancillary information on the atmospheric conditions at the moment of image acquisition does not exist, making it impossible to apply an absolute atmospheric correction model to the image.

The assumption of homogeneous substrate and unchanging water quality for the entire image was another potential source of errors. The albedo and reflective properties of the substrate and the quality of the water were likely to vary in such heterogeneous 
structures as coral reefs are. Coral cays and reef fronts are often interspersed by bare sand over a few meters. Due to the resolution of the data used, a generalisation of reflectance over a very heterogeneous area of $900 \mathrm{~m}^{2}$ was made. This created some radiometric uncertainty about what bottom type exactly was represented by the recorded DN-value.

Other errors were generated by the sampling method and the spatial uncertainty of the satellite data used. While making depth measurements from the Zodiac, the position of the vessel was unstable due to movements caused by currents and waves. Generally, this would not produce large deviations and, with a resolution of $30 \mathrm{~m}$ of the satellite data used, the deviations would be negligible. Nevertheless if an observation was situated near an «edge» of a pixel, uncertainty raised which DN-value corresponded to the depth measured. Errors of GPS-readings were also occurring, but with a general deviation of 3 to $4 \mathrm{~m}$, these errors were again most of the time small confronted with the spatial resolution of the data.

\section{Conclusions}

The PhD-study in which this paper concerning bathymetric mapping frames, investigates the possibilities to develop a monitoring system for the coral reefs in the Red Sea based on remote sensing. Remote sensing techniques are used firstly to derive information about the location of the coral reefs (X-, Y-coordinates), the depth at which they occur (Z-coordinates, bathymetry), their structure (delineation between different bottom types such as coral, algae, seagrass and sand) and their condition. On a regional scale, remote sensing contributes in monitoring the physical, chemical and/or ecological conditions of the Red Sea.

Bathymetric mapping of coral reefs using remote sensing has the advantages of reaching areas which are not easily accessible by conventional sounding boats, of working over large areas in a synoptic way and of analysing the evolution multitemporally. The modified «depth of penetration»-mapping method used in this paper gave reasonable results in a rather fast and easy way. But as can be seen after accuracy testing, some deviations from ground-truth occurred. There is still a need for sound atmospheric and radiometric correction of the satellite data and a sufficient set of ground-truth data, preferably over a homogeneous, highly reflective substrate.

The remote sensing based results together with additional information concerning the coral reefs, threats posed on them or the condition of the Red Sea, are integrated in a "Coral Reef GIS». This GIS can be used to support integrated coastal zone management (ICZM) by local government, coastal developers, environmentalists or other decision makers. If the ICZM also takes care of data management and education of the local communities, it will form the key for the sustainable development of the Egyptian Red Sea coast (Wilson et al., 1998). 


\section{BIBLIOGRAPHY}

BENNY A. \& DAWSON G. (1983), «Satellite imagery as an aid to bathymetric charting in the Red Sea», The Cartographic Journal, 20, 1, Leeds (UK), Maney Publishing pp. 5-16.

EDWARDS A. (ed.) (1999), «Applications of Satellite and Airborne Image Data to Coastal Management», Coastal region and small island papers, 4, Paris, UNESCO.

EDWARDS F.J. (1987), «Climate and Oceanography», in EDWARDS A.J. \& HEAD S.M. (eds.), Key Environments: Red Sea, Oxford, Pergamon Press, pp. 45-69.

GREEN E., EDWARDS A. \& MUMBY P. (2000), «Mapping Bathymetry», in EDWARDS A. (ed.), Remote Sensing Handbook for Tropical Coastal Management, Paris, UNESCO, pp. 219-235.

GREEN E., MUMBY P., EDWARDS A. (ed.) \&. CLARK C. (2000), «Remote Sensing Handbook for Tropical Coastal Management», Coastal Management Sourcebooks, 3, Paris, UNESCO.

JERLOV N.G. (1976), «Marine Optics», Elsevier Oceanographic Series, 14, Amsterdam, Elsevier Scientific Publishing Company.

JI W. CIVCO D. \& KENNARD W. (1992), «Satellite Remote Bathymetry: A New Mechanism for Modelling», Photogrammetric Engineering \& Remote Sensing, 58, 5, Bethesda (USA), ASPRS, pp. 545-549.

JUPP D. (1988), Background and extensions to depth of penetration (DOP) mapping in shallow coastal waters, Proceedings of the Symposium on Remote Sensing of the Coastal Zone, Brisbane, Department of Geographic Information, pp. IV.2.1-IV.2.19.

LYZENGA D. (1978), «Passive remote sensing techniques for mapping water depth and bottom features», Applied Optics, 17, 3, Washington, Optical Society of America, pp. 379-383.

MUMBY P.J., CLARK C.D., GREEN E.P. \& EDWARDS A.J. (1998), «Benefits of water column correction and contextual editing for mapping coral reefs», International Journal of Remote Sensing, 19, 1, London, Taylor \& Francis Ltd, pp. 203-210.

VANDERSTRAETE T., GOOSSENS R. \& GHABOUR T. (2002), Bathymetric mapping of coral reefs in the Red Sea (Hurghada-Egypt) using Landsat7 ETM+ Data, Proceedings of the Seventh International Conference on Remote Sensing for Marine and Coastal Environments, Ann Arbor (USA), Veridian, CD-ROM

VAN HENGEL W. \& SPITZER D. (1991), «Multi-temporal water depth mapping by means of Landsat TM», International Journal of Remote Sensing, 12, 4, London, Taylor \& Francis Ltd, pp. 703-712.

WILSON M., DE MEYER K. \& SKEAT H. (1998), The GEF Egyptian Red Sea Coastal and Marine Resource Management Project - A Decade of Effort and Trade-Offs Required to Achieve Marine Tourism and Conservation Goals, International Marine Ecosystems Management Symposium Proceedings, pp. 239-250, Townsville (Australia), GBRMPA.

\section{NOTES}

1. WXTide32 version 2.6, 20/01/2000, (C1998-2000, Michael Hopper, http://www.GeoCities.com/ SiliconValley/1195/.

2. ILWIS 2.23, The Integrated Land and Water Information System, OITC, ILWIS Development, August 1999. 
3. UK Hydrographic Office, Nautical Chart 3034: Red Sea - Ports of the coast of Egypt - B. Hurghada, scale: 1:25000, Transverse Mercator Projection, Taunton (UK), 1997.

\section{ABSTRACTS}

For monitoring coral reefs, a bathymetric map is useful as a base map. Different methods have already been developed to map bathymetry using remote sensing. Two main groups can be distinguished. One group is using active remote sensing data; the other is based on passive sensor generated multi-spectral information. In this article, the focus is on the passive data method. A modified «depth of penetration» mapping method was implemented on a Landsat7 ETM+-image over Hurghada (Egypt). Some 420 depth measurements were used for ground-truthing and accuracy testing. The accuracy test revealed that the resulting bathymetric map is useful for coral reef mapping, but care should be taken when using it. Deviations from reality were caused by assumptions inherent to the theory used, field sampling, satellite image characteristics and errors during implementation of the method.

Een bathymetrische kaart vormt een van de basiselementen voor het bestuderen van koraalriffen. Verschillende methodes werden reeds ontwikkeld voor het bepalen van de diepte met behulp van teledetectie. Twee belangrijke groepen kunnen hierin onderscheiden worden. De ene groep baseert zich op informatie verkregen van actieve sensoren, de andere gebruikt multispectrale data afkomstig van passieve sensorsystemen. In dit artikel wordt enkel de passieve sensor methode besproken. Een aangepaste «Depth of Penetration» karteringsmethode werd toegepast op een Landsat7 ETM+-beeld over Hurghada, Egypte. 420 dieptemetingen werden gebruikt voor het absoluut determineren van de afgeleide diepte en voor het bepalen van de nauwkeurigheid van het resultaat. Hieruit bleek dat de resulterende dieptekaart gebruikt kan worden bij het karteren van de koraalriffen. Toch is enige voorzichtigheid bij het gebruik gewenst. Fouten werden veroorzaakt door veronderstellingen inherent aan de toegepaste theorie, de gebruikte waarnemingstechnieken, de kenmerken van het satellietbeeld en fouten bij de implementatie van de methode.

\section{INDEX}

Keywords: remote sensing, bathymetry, coral reefs, Red Sea

Trefwoorden teledetectie, bathymetrie, koraalriffen, Rode Zee

\section{AUTHORS}

\section{TONY VANDERSTRAETE}

Research Assistant of the Fund for Scientific Research - Flanders (Belgium) (F.W.O.-Vlaanderen), Department of Geography, Ghent University, Belgium, tony.vanderstraete@UGent.be 


\section{RUDI GOOSSENS}

Department of Geography, Ghent University, Belgium, rudi.goossens@UGent.be

\section{T.K. GHABOUR}

Soils and Water Use Department, National Research Centre El Dokki, Cairo, Egypt 